\title{
高齢者の身体活動活性化のためのゲームシステムの改良と評価
}

\author{
○遠藤直人，大須賀美恵子（大阪工業大学工学部）
}

\section{Improvement and evaluation of a game system for activating elderly people's body activity}

Naoto ENDO, Mieko OHSUGA (Faculty of Engineering, Osaka Institute of Technology)

\section{1.はじめに}

日本は超高齢社会を迎え, 要介護者が増加し ている. 介護予防として身体機能維持，低下の 緩和を支援する方策が望まれている.岩谷らは, 高齢者施設のグループレクリエーション向け の多人数参加型のゲームシステムを開発し, 評 価をしてきた ${ }^{1)}$. 使用者の心の活性化を示すこ とはできたが, 身体活動の活性化を示すことは できなかった。本研究では，これまでのシステ ムの長所を継承しつつ，問題点を改良し，運動 の活性化を調べる。

\section{2. ゲームシステムの開発 \\ 2. 1 既存システム}

既存システムの入力は, 腿を上げる運動また は手を握る運動の 2 つであった. 図 1 左が縄跳 びゲーム，図 1 右が足踏みゲームである。ゲー ムはActionscript3.0 で製作している.縄跳び は, 縄のタイミングに合わせて足を大きく上げ るか, 手を握ることで縄を跳び，綱引きは，足 を速く動か寸か, 手を握る運動を速く繰り返す ことで綱を引くことができる.

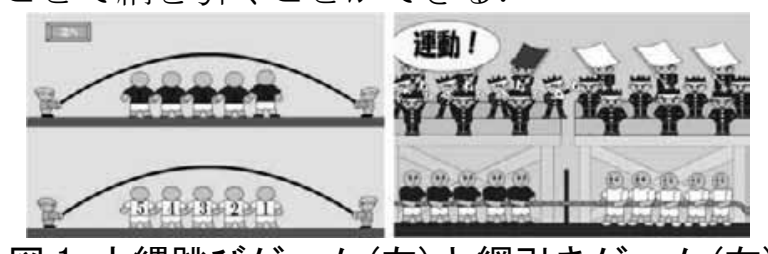

図 1 大縄跳びゲーム (左)と綱引きゲーム(右)

下肢の運動を検出して，PC に送る入力装置 を図 2 左に示す。これは, 3 軸加速度センサ （KXM52-1050）と無線通信のための XBee (series1) 加成る. 重力加速度の変化より, 腿の角度を求めている. 入力装置を図 2 右のゼ ッケンに入れて大 腿に固定する。こ の入力装置及びゼ ッケンは, 高齢者 の運動を束縛せず, 脱着を簡便にして

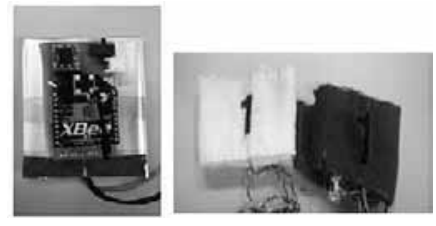

図 2 加速度センサ (左)とゼッケン(右)
力装置は，本研究でも使用する.

\section{2 改良}

手を握る運動は, 足を動かせない人の参加を 可能にしていたが，2種類の運動があると使用 者が混乱するという問題が発生した。 そこで, 今回は下肢の運動のみに絞った。

高齢者向けのゲームには, 直感的にわかるこ とと意欲を持続できることが必要である.これ らの観点からこれまでのゲームの問題点を抽 出し，それらを踏まえて新しいゲームを開発し $た^{2)}$. 大縄跳びゲームは，わかりやすいが，夕 イミングをとるのが難しかった。また，閾值を 設定して入力を 2 值化していたため, 大きな動 きを引き出すことができなかった，そこで，風 船割りゲームとパン食いゲームを製作した(図 3). 腿の角度に連動して10段階にキャラクタが 上下し，降下寸る風船やパンと接触させる．高 い位置で捉えた方が高得点となるよう設定す ることで，より高く腿を上げる意欲が高まるこ とを期待した。

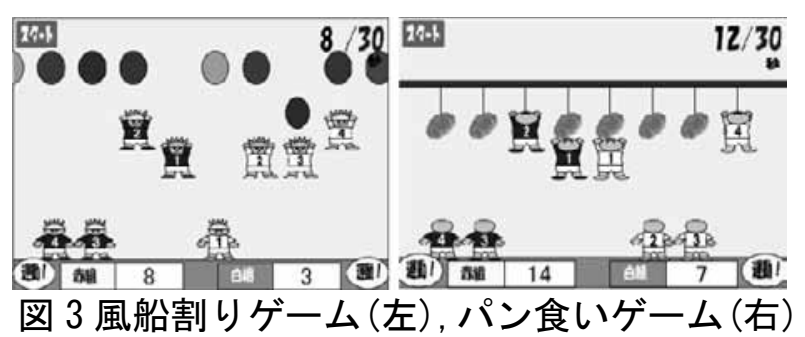

綱引きゲームは, 足踏みで綱を引くことの対 応が悪くわかりにくかった。そこで，足踏みで かけっこをするというわかりやすいゲームを 製作した(図4)。また, 綱引きは個人の貢献が わかりにくかったが，か けっこでは順位が明確 で，競争意欲が高まるこ とを期待した. 個人の得 点和でチームの勝敗が 決するようにもし，動機

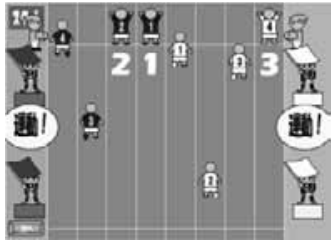
付けを高める工夫をした，図4かけっこゲーム 
試作したゲームを高齢者施設で試用した結 果, 腿上げゲームで足を 下ろさないという例が 発生した。 そこで，足を 下ろす動機付けのため, キャラクタの足元にト ランポリンを設置し, 毎 回着地して跳びあがる という設定にした(図5)。

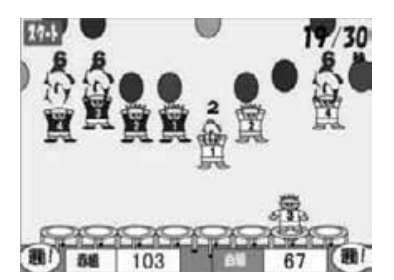

図5 改良したゲーム

\section{4. 評価実験}

改良したシステムの運動の活性化効果を調 べるため，介護老人保健施設「おひさま園」を 計 4 回訪問した. 利用者に新規ゲームと既存ゲ 一ムを使用してもらった．実験参加者は，イン フォームド・コンセントを本人または家族から 得た 18 名 (男性 5 名, 女性 13 名, 要介護度 1 〜4)である. そのうち 8 名は軽度〜中度の認知 症で，4名は片麻痺があった。1 回の実験で最 大 8 名に参加してもらった。ゲームは, 腿上げ ゲームの後に足踏みゲームを行う。それぞれ開 始前に準備運動をする.腿上げは，奇数回は新 ゲームから, 偶数回は旧ゲームから始め, 足踏 みは, 奇数回では旧ゲームから, 偶数回では新 ゲームから始めた。準備運動では，ゲームのな い状態で, 掛け声に合わせて腿の上げ下げまた は足踏み運動をしてもらう。なお，この実験計 画は大阪工業大学ライフサイエンス実験倫理 委員会の審査に基づき, 大阪工業大学大学長の 承認を得ている(承認番号 2012-32).

\section{5. 結果}

準備運動時とゲーム中の腿上げ角度や足踏 み速度を比較した。腿上げ角度は，センサを付 けた腿の上げ始めの角度と下ろし始めの角度 の差であり, 準備運動中とゲーム中の回数にお ける平均を求める. 足踏みは，センサを付けた 足の上げ始めから上げ始めにかかる時間を求 め, 準備運動中とゲーム中の平均を求める。 そ こから 1 分間に何回足踏みをするかを足踏み 速度とする.ゲーム中の值を準備運動時の值で 割り，それを活性度とし，その值が 1.2 以上だ った場合に運動が活性化したとした。

日毎の実験データにおいて, 参加者のうち何 人の運動が活性化したかを割合として求め, 活 性化率とした (図 6)。腿上げゲームの活性化率 は，どれも実施を繰り返すと増加する傾向があ り, 新規ゲーム 2 種はその度合いが大きかった。 足踏みゲームの活性化率は, 回数には影響され なかった。
4 回とも参加した 8 名について, 活性度の日 毎の平均をまとめた (図 7)。腿上げゲームは増 加傾向，足踏みゲームは減少傾向を示した。ゲ 一ムの種類・実施回数を要因とする, 繰り返し のある 2 元配置の分散分析を行った (有意水準 $5 \%)$ ．腿上げゲームでは，実施回数の主効果が あり, 交互作用はなかった. 足踏みゲームでは, 主効果，相互作用とも有意でなかった.

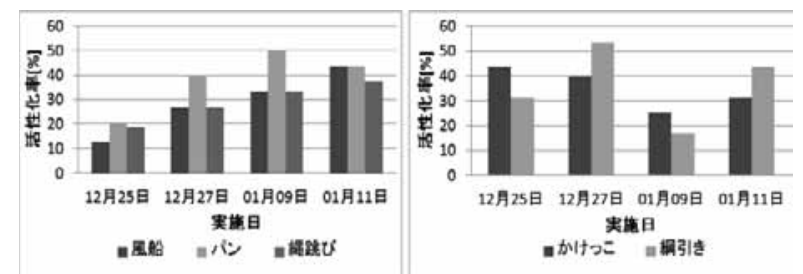

図 6 腿上げ(左)と足踏み(右)の活性化率

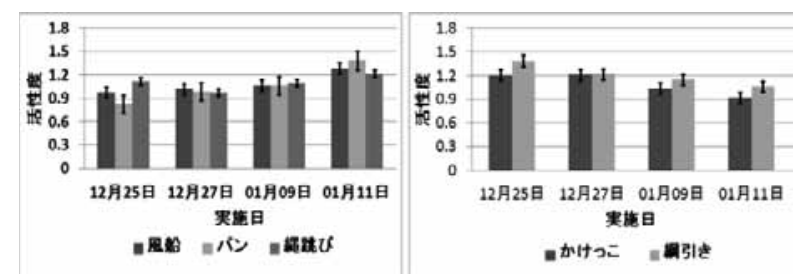

図 7 腿上げ(左)と足踏み(右)の活性度

\section{6. 結論}

新しい腿上げゲームは, 既存のゲームと比較 して運動の活性化が期待できることがわかっ た. 足の角度とゲームキャラクタの位置を連動 させるということが効果的に働いたと考えら れる、新しい足踏みゲームに関しては, 活性化 を示すことができなかった. 個人競技であるか けっこゲームでは, 誰かゴールすることでモチ ベーションが下がり減速するなど, 運動意欲の 維持ができなかったのではないかと考えられ る.わかりやすいという点においては, 参加者 から高評価を得ることができた．より直感的に わかりやすく，持続的な運動ができるようなゲ 一ムを改良，開発することで，更なる身体活動 の活性化効果が期待できると思われる。

\section{参考文献}

1）岩谷智一 他：“高齢者のグループレクリエ ーションに適した遊びリテーションシス テムの開発と評価”, 信学技報, vo1. 112, No. 65, pp. 45-48, 2012

2）遠藤直人 他：“高齢者の体の動きを入力と するグループレクリエーション向けゲー ムシステムの開発”，平成 24 年度日本人 間工学会関西支部大会講演論文集, pp. 95-96, 2012 